\title{
PENGARUH PUPUK ORGANIK CAIR KEONG MAS (Pomacea canaliculata L.) DAN PAKLOBUTRAZOL TERHADAP PERTUMBUHAN PADI VAR. MAPAN P-05
}

\author{
EFFECT OF ORGANIC FERTILIZER LIQUID GOLD SNAILS (Pomacea \\ canaliculata L.) AND PACLOBUTRAZOL ON THE GROWTH OF RICE \\ VAR. MAPAN P-05
}

\author{
Ngadiani*, Diah Karunia Binawati, Vivin Andriani \\ Fakultas Matematika dan Ilmu Pengetahuan Alam, \\ Universitas PGRI Adi Buana Surabaya. Surabaya, Indonesia \\ *Email:ngadiani@unipasby.ac.id
}

\begin{abstract}
Rice (Oryza sativa L.) is the main food of people in Indonesia. Barriers that occur are the rice harvest season that is not in line with farmers' expectations. Improvement of soil physical and chemical properties to increase dry land productivity can be done with the support of organic matter. Therefore, increased productivity must be increased, one of them is the application of POC gold snail and paklobutrazol. The purpose of this research is to determine the effect of POC gold snails and paklobutrazol on the growth and anatomy of rice plants (Oryza sativa L.). To determine the amount of POC concentrations of golden snails and paklobutrazol which are effective in increasing the growth and anatomy of rice (Oryza sativa L.). The research was design by completly randomized block design (RCBD) factorial, with 2 factors, namely the dose of LOF golden snail and paklobutrazol. Doses of liquid organic fertilizer consist of 4 levels, namely: control $=0 \mathrm{ml} / \mathrm{L}(\mathrm{CO}), 1 \mathrm{ml} / \mathrm{L}(\mathrm{C1}), 1.5 \mathrm{ml} / \mathrm{L}(\mathrm{C2})$, or $2 \mathrm{ml} / \mathrm{L}(\mathrm{C} 3)$. Application of liquid organic fertilizer is done 4, 8 and 12 weeks after rice transplanting. The dose of paklobutrazol in rice plants with 4 levels, namely: Control 0 ppm paklobutrazol (P0), 5 ppm paklobutrazol (P1), 10 ppm paklobutazol (P2), or 15 ppm paklobutazol (P3). This analysis was carried out using SPPS Software 21. The application of golden LOC and paklobutrazol has an effect on plant height, number of leaves and age of flag leaf discharge on Mapan P-05 rice plants.
\end{abstract}

Keywords: LOF, Mapan P-05 rice plant, gold snail, growth, paklobutrazol

\begin{abstract}
ABSTRAK
Padi (Oryza sativa L.) merupakan makanan pokok sebagian masyarakat di Indonesia. Hambatan yang terjadi yaitu musim panen padi yang tidak sesuai harapan petani. Perbaikan sifat fisik dan kimia tanah untuk peningkatan produktivitas lahan kering dapat dilakukan diantaranya dengan penambahan bahan organik. Oleh karena itu, produktivitas padi harus ditingkatkan, salah satunya dengan aplikasi POC keong mas dan pklobutrazol. Tujuan penelitihan ini, yaitu untuk mengetahui pengaruh POC keong mas dan paklobutrazol terhadap pertumbuhan dan anatomi tanaman padi (Oryza sativa L.) serta untuk menentukan berapa konsentrasi POC keong mas dan paklobutrazol yang efektif meningkatkan pertumbuhan dan anatomi padi (Oryza sativa L.). Rancangan yang digunakan dalam penelitian ini adalah rancangan acak kelompok lengkap (RAKL) pola faktorial, dengan 2 faktor perlakuan yaitu dosis POC keong mas dan paklobutrazol. Dosis pupuk organic cair terdiri atas 4 tingkat,
\end{abstract}


yaitu: $k$ ontrol $=0 \mathrm{ml} / \mathrm{L}(\mathrm{C} 0), 1 \mathrm{ml} / \mathrm{L}(\mathrm{C} 1), 1,5 \mathrm{ml} / \mathrm{L}(\mathrm{C} 2)$, atau $2 \mathrm{ml} / \mathrm{L}(\mathrm{C} 3)$. Aplikasi pupuk organik cair dilakukan pada saat tanaman padi berumur 4, 8 dan 12 minggu setelah pemindahan. Dosis pemberian paklobutrazol pada tanaman padi dengan 4 tingkat, yaitu: Perlakuan kontrol $=0$ ppm paklobutrazol (P0), 5 ppm paklobutazol (P1), 10 ppm paklobutazol (P2), atau 15 ppm paklobutazol (P3). Analisis data dilakukan dengan menggunakan Software SPPS 21 pada taraf 5\%. Pemberian POC keong mas dan paklobutrazol memberikan pengaruh pada tinggi tanaman, jumlah daun dan umur keluarnya daun bendera pada tanaman Padi Var. Mapan P-05.

Kata kunci: Keong mas, Padi Var. Mpan P-05, POC, paklobutrazol, pertumbuhan

\section{PENDAHULUAN}

Padi (Oryza satival) merupakan makan pokok masyarakat Indonesia. Kebutuhan beras setiap tahun meningkat seiring bertambahnya jumlah penduduk. Produksi padi mengalami penurunan pada tahun 2019 sebesar 7,76 persen dibandingkan dengan tahun 2018. Jika produksi padi dikonversikan menjadi beras pada tahun 2018 sebesar 33,94 juta ton sedangkan pada tahun 2019 sebesar 31,31 juta ton (BPS, 2020).

Salah satu penyebab tidak optimalnya produksi padi adalah tingginya pemupukan anorganik pada lahan sawah. Dampak pemupukan tersebut menyebabkan menunrunnya kandungan bahan organik tanah. Menurut hasil penelitian Badan Litbang Pertanian (2006) tingkat kesuburan lahan sawah Indonesia semakin menurun. Sekitar $65 \%$ dari 7,5 juta ha lahan sawah irigasi di Indonesia memiliki kandungan bahan organik dalam kategori sedang karena kandungan bahan organiknya kurang dari $2 \%$, dimana dalam kondisi normal minimal mengandung 3\% bahan organik.

Untuk memperbaiki bahan organik pada tanah salah satunya dengan cara pemberian pupuk organik yang berasal dari bagian tumbuhan maupun hewan. Salah satu yang dapat digunakan sebagai pupuk organik adalah keong mas. Menurut Suhastyo et al. (2013), keong mas mengandung unsur $\mathrm{Na}, \mathrm{Mn}, \mathrm{K}, \mathrm{C}, \mathrm{Cu}, \mathrm{Ca}$,
P, dan Zn. Sedangkan Menurut Chaniago (2015), keong mas mengandung protein sebesar $59,83 \%$ dan asam amino dengan komposisi: arginin 18,9\%, histidin $2,8 \%$, isoleusin $9,2 \%$, leusin $10 \%$, lisin $17,5 \%$, methionin $2 \%$, phenilalamin $7,6 \%$, threonin $8,8 \%$, triptofan $1,2 \%$, dan valin $8,7 \%$. Triptofan merupakan senyawa prekursor pembentuk Indole Acetic Acid (IAA).

Selain memperbaiki bahan organik pada tanah untuk meningkatan hasil panen padi dapat juga ditambahkan perlakuan paklobutrazol untuk mempercepat proses pertumbuhan vegetatif sehingga mempercepat perkembangan generatif. Paklobutrazol berfungsi sebagai salah satu zat penghambat pertumbuhan yang bekerja pada bagian meristem yang menghambat sintesis giberelin dengan cara menghambat aktivitas enzim yang mengkatalis biosintesis kaurin menjadi asam kaurenoic (Hedden, 2005).

\section{BAHAN DAN METODE}

\section{Tempat dan Waktu}

Penelitian dilakukan di Kebun PercobaanProgram Studi Biologi FMIPA Universitas PGRI Adi Buana Surabaya, Jawa Timur pada bulan November 2019.

\section{Rancangan Penelitian}

Rancangan yang digunakan dalam penelitian ini adalah rancangan acak kelompok lengkap (RAKL) 
faktorial, dengan 2 faktor perlakuan yaitu dosis POC keong mas yang terdiri dari 4 tingkat, yaitu: kontrol = $0 \mathrm{ml} / \mathrm{L}(\mathrm{M} 0), 1 \mathrm{ml} / \mathrm{L}(\mathrm{M} 1), 1,5 \mathrm{ml} / \mathrm{L}(\mathrm{M} 2)$, atau $2 \mathrm{ml} /$ L (M3) dan dosis paklobutrazol dengan 4 tingkat, yaitu: kontrol $=0 \mathrm{ppm}(\mathrm{P} 0), 5 \mathrm{ppm}(\mathrm{P} 1), 10 \mathrm{ppm}$ (P2), dan 15 ppm (P3). Aplikasi pupuk organik cair dilakukan pada saat tanaman padi berumur 4, 8 dan 12 minggu setelah pemindahan. Untuk masing-masing kombinasi perlakuan digunakan 3 ulangan, sehingga jumlah sampel yang digunakan adalah 48 sampel tanaman Padi Var. Mpan P-05.

\section{Pelaksanaan Penelitian}

\section{Pembuatan fermentasi keong mas}

Keong mas dipisahkan antara daging dan cangkangnya, kemudian ditumbuk. Selanjutnya $1 \mathrm{~kg}$ cangkang keong mas dicampur dengan $500 \mathrm{ml}$ molasses, 4 liter air cucian beras dan 160 ml EM4 kemudian masukkan kedalam ember dan ditutup rapat. Fermentasi dilakukan selama 14 hari. Setelah itu hasil fermentasi disaring dan diencerkan sampai volume mencapai $1000 \mathrm{ml}$ untuk setiap konsentrasi.

Persiapan media semai dan Penyemaian Benih.

Tanah dibersihakan dan dihaluskan agar tanah menjadi gembur. Kemudian dimasukkan kedalam wadah penyemaian. Sebelum benih disebar, benih terlebih dahulu direndam air selama 24 jam. Kemudian disebar pada box persemaian yang telah disiapkan. Media semai dibasahi dengan paklobutrazol sesuai dengan perlakuan kontrol $=0$ ppm paklobutrazol (P0), 5 ppm paklobutazol (P1), 10 ppm paklobutazol (P2), atau 15 ppm paklobutazol (P3). Kelembaban benih dipertahankan dengan cara menyiram media semai dengan air setiap pagi atau sore hari.

\section{Penyiapan media tanam}

Sebelum tanah dimasukkan ke dalam pot ukuran $15 \mathrm{~kg}$ dengan diameter $30 \mathrm{~cm}$ terlebih dahulu tanah dihaluskan dan dibersihkan dengan tujuan agar kotoran lain tidak terikut. Kemudian tanah tersebut dicampurkan dengan media tanam kemasan dan kompos (2:1) dan diaduk sampai rata. Setelah itu tanah yang sudah dicampurkan dengan media tanam dimasukkan ke dalam pot dan diisi air sampai tergenang $1 \mathrm{~cm}$ dari permukaan tanah.

\section{Pemindahan bibit padi}

Setelah berumur 15 hari bibit tanaman padi dipindahkan dari media semai ke media tanam yang telah dipersiapkan. Untuk satu pot dimasukkan 2 bibit tanaman padi. Setelah tanaman padi berumur 2 minggu setelah pemindahan, hanya satu tanaman padi yang dibiarkan untuk tumbuh.

\section{Pemeliharaan Tanaman}

Pada saat berumur 2-3 hari setelah tanam (hst), kondisi media tanam tetap dipertahankan dalam keadaan basah. Setelah itu sesuai dengan tingkat pertumbuhan tanaman, genangan air diusahakan mencapai $5 \mathrm{~cm}$. Pemupukan dilakukan dengan menggunakan POC cangkang keong mas cair pada saat tanaman berumur 4, 8 dan 12 minggu setelah tanam sesuai dengan perlakuan: $k$ ontrol $=0 \mathrm{ml} / \mathrm{L}(\mathrm{C} 0), 1 \mathrm{ml} /$ L(C1), 1,5ml/L (C2), dan 2m1/L (C3).

Penyiangan dilakukan secara manual dilakukan secara rutin dengan tujuan untuk membebaskan tanaman Padi Var. Mpan P-05 dari gulma pengganggu tanaman. Pengendalian hama dan penyakit dilakukan secara intensif.

Pengamatan. Adapun parameter yang dimati 
adalah tinggi tanaman, jumlah daun dan Umur tanaman padi hitam saat keluar daun bendera.

Analisis Data.

Semua data hasil pengamatan dianalisis statistika SPSS 21, analisis varian satu arah pada taraf signifikansi 0,05. Uji lanjut untuk mengetahui perbedaan antarperlakuan dilakukan dengan menggunakan UjiBNT (Beda Nyata Terkecil) dengan taraf signifikansi 0,05.

\section{HASIL DAN PEMBAHASAN}

Tinggi batang tanaman padi Var. Mapan P-05.

Pengamatan tinggi tanaman padi Var. Mapan P-05dengan berbagai perlakuan paklobutrazol dan pupuk organik keong mas, hasil uji BNT pada tarag $5 \%$ menunjukkan berbeda yang nyata antara perlakuan paklobitrazol dan POC keong mas (tabel 1).

Rerata tinggi batang tanaman padi Var. Mapan P-05 dengan berbagai perlakuan paklobutrazol dan pupuk organik keong mas disajikan pada gambar 1 .

Berdasarkan gambar 1, terlihat bahwa pada kombinasi paklobutrazol dan pupuk organik keong mas menunjukkan berpengaruh terhadap rerata tinggi tanaman pada umur 12 MST. Hal tersebut dapat dimungkinkan pupuk organik keong mas yang diaplikasikan sebanyak 3 kali selama 12 MST sudah mampu menyeimbangi efek yang diberikan

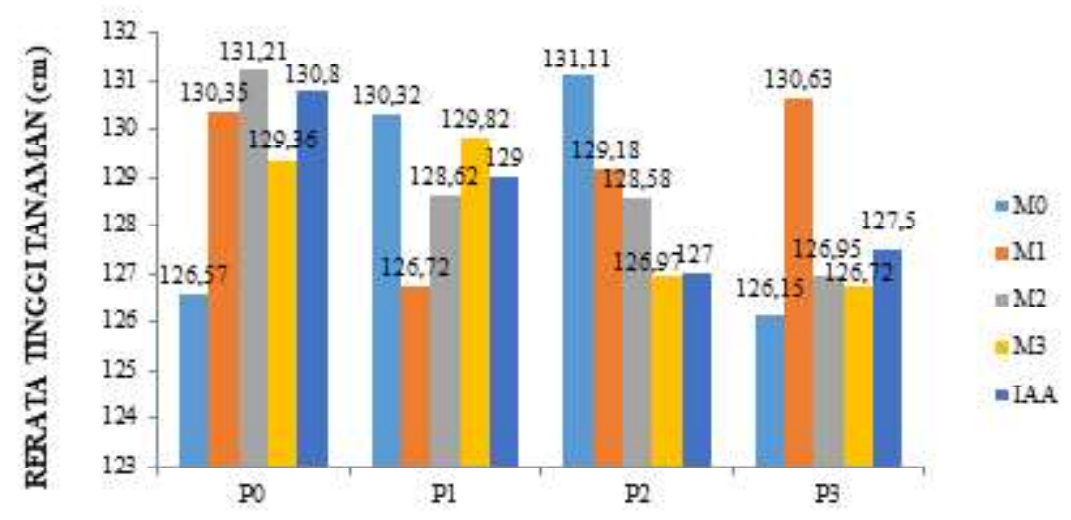

PERLAKUAN

Gambar 1. Rerata tinggi tanaman Padi Var. Mpan P-05 setelah 12 MST.

Tabel 1. Rerata tinggi batang $(\mathrm{cm})$ tanaman Padi Var. Mpan P-05 dengan berbagai perlakuan konsentrasi paklobutrazol dan pupuk organik cangkang keong mas setelah 12 minggu setelah pindah tanam(MST).

\begin{tabular}{cccccc}
\hline $\begin{array}{c}\text { Konsentrasi } \\
\text { Paklobrutazol } \\
\text { (ppm) }\end{array}$ & \multicolumn{2}{c}{ Konsentrasi Pupuk Organik Cangkang Keong Mas (ml/L) } & IAA \\
\cline { 2 - 5 } & $\mathbf{M 0}$ & $\mathbf{M 1}$ & $\mathbf{M} 2$ & $\mathbf{M 3}$ & \\
\hline P0 (0ppm) & $126,57^{\mathrm{a}}$ & $130,35^{\mathrm{bc}}$ & $131,21^{\mathrm{c}}$ & $129,36^{\mathrm{b}}$ & $130,8^{\mathrm{c}}$ \\
P1 (5ppm) & $130,32^{\mathrm{b}}$ & $126,72^{\mathrm{a}}$ & $128,62^{\mathrm{ab}}$ & $129,82^{\mathrm{b}}$ & $129,0^{\mathrm{b}}$ \\
P2 (10ppm) & $131,22^{\mathrm{c}}$ & $129,18^{\mathrm{b}}$ & $128,58^{\mathrm{b}}$ & $126,97^{\mathrm{a}}$ & $127,0^{\mathrm{a}}$ \\
P3 (15ppm) & $126,15^{\mathrm{a}}$ & $130,63^{\mathrm{b}}$ & $126,95^{\mathrm{a}}$ & $126,72^{\mathrm{a}}$ & $127,5^{\mathrm{a}}$ \\
\hline
\end{tabular}

Keterangan: Angka rerata yang diikuti huruf yang sama pada kolom yang sama menunjukkan tidak berbeda nyata pada taraf uji BNT $5 \%$. 
paklobutrazol, sehingga tinggi tanaman pada antar kombinasi tidak berbeda nyata.

Pemberian paklobutrazol yang diaplikasikan,pada tanaman semakin tinggi maka semakin rendah rerata tinggi tanaman. Pertumbuhan tanaman akan tertekan oleh paklobutrazol disebabkan senyawa paklobutrazol membuat tidak aktifnya tiga tahap pada jalur terpenoid terpisah dalam memproduksi giberelin dengan cara berikatan dan menghambat enzim yang mengkatalis reaksi metabolisme. Tiga tahapan yang akan mengalami gangguan oleh paklobutrazol yaitu reaksi perubahan entKaurene menjadi ent-Kaurenol, ent-Kaurenol menjadi ent-Kaurenal, dan ent-Kaurenal menjadi ent-Kaurenoid acid (Warner dan Erwin, 2003; Sinniah et al., 2011).

Peran giberelin pada tanaman yaitu sebagai pemicu pertumbuhan dari awal proses perkecambahan sampai tahap seneses serta pembelahan dan perbesaran sel (Richards et al., 2001). Pada saat produksi giberelin terhambat, pembelahan sel akan tetap terjadi, tetapi pada sel yang baru tidak bisa memanjang. Sehingga jumlah daun pada tajuk sama dan adanya penekanan pada bagian internodus yang mengakibatkan bagian tersebut menjadi pendek. Penutupan pada sistem jalur terpenoid akan menyebabkan pengalihan terakumulasinya senyawa intermediet diatas penutupan (Chaney, 2005). Hasil dari penelitian ini sama dengan penelitian yang dilakukan oleh Tumewu et al. (2012), bahwa pemberian paklobutrazol 500 atau 1000 ppm pada tanaman jagung manis bersifat menurunkan rerata tinggi tanaman dan meningkatkan produktivitas dibandingkan dengan kontrol. Widaryanto et al. (2011), mengungkapkan bahwa semakin tingggi pengaplikasian dosis paklobutrazol menyebabkan semakin potensial menghambat tinggi tanaman.

\section{Jumlah daun tanaman Padi Var. Mapan P-05}

Pengamatan jumlah daun tanaman padi Var. Mapan P-05 dengan berbagai perlakuan paklobutrazol dan pupuk organik keong mas, hasil uji BNT pada tarag $5 \%$ menunjukkan berbeda yang nyata antara perlakuan paklobitrazol dan POC keong mas (tabel 2).

Rerata jumlah daun tanaman Padi Var. Mpan P05 setelah pindah tanam dengan berbagai perlakuan konsentrasi paklobutrazol dan pupuk organik keong mas disajikan pada gambar2. Berdasarkan gambar 2, diperoleh bahwa, kombinasi aplikasi P1 (paklobutrazol 5 ppm)

Tabel 2. Rerata jumlah daun tanaman padi Mapan P-05 dengan berbagai perlakuan konsentrasi paklobutrazol dan pupuk organik cangkang keong mas setelah 12 minggu setelah pindah tanam (MST).

\begin{tabular}{|c|c|c|c|c|c|}
\hline \multirow{2}{*}{$\begin{array}{l}\text { Konsentrasi } \\
\text { Paklobrutazol } \\
\quad \text { (ppm) }\end{array}$} & \multicolumn{4}{|c|}{ Konsentrasi Pupuk Organik Cangkang Keong Mas (ml/L) } & \multirow[b]{2}{*}{ IAA } \\
\hline & $\begin{array}{c}\text { M0 } \\
\text { (0ml) }\end{array}$ & $\begin{array}{c}\text { M1 } \\
\text { (1ml) }\end{array}$ & $\begin{array}{c}\mathrm{M} 2 \\
(1,5 \mathrm{ml})\end{array}$ & $\begin{array}{c}\text { M3 } \\
\text { (2ml) }\end{array}$ & \\
\hline $\mathrm{P} 0(0 \mathrm{ppm})$ & $82^{\mathrm{d}}$ & $83^{\mathrm{d}}$ & $74^{\mathrm{bc}}$ & $74^{\mathrm{bc}}$ & $72^{\mathrm{b}}$ \\
\hline $\mathrm{P} 1(5 \mathrm{ppm})$ & $77^{\mathrm{c}}$ & $80^{\text {cd }}$ & $70^{\mathrm{b}}$ & $81^{\mathrm{d}}$ & $81^{\mathrm{d}}$ \\
\hline $\mathrm{P} 2$ (10ppm) & $75^{\mathrm{bc}}$ & $77^{\mathrm{c}}$ & $79^{\mathrm{c}}$ & $67^{\mathrm{a}}$ & $77^{\mathrm{c}}$ \\
\hline P3 (15ppm) & $71^{\mathrm{b}}$ & $72^{\mathrm{b}}$ & $63^{\mathrm{a}}$ & $60^{\mathrm{a}}$ & $63^{\mathrm{a}}$ \\
\hline
\end{tabular}

Keterangan: Angka rerata yang diikuti huruf yang sama pada kolom yang sama menunjukkan tidak berbeda nyata pada taraf uji BNT $5 \%$. 


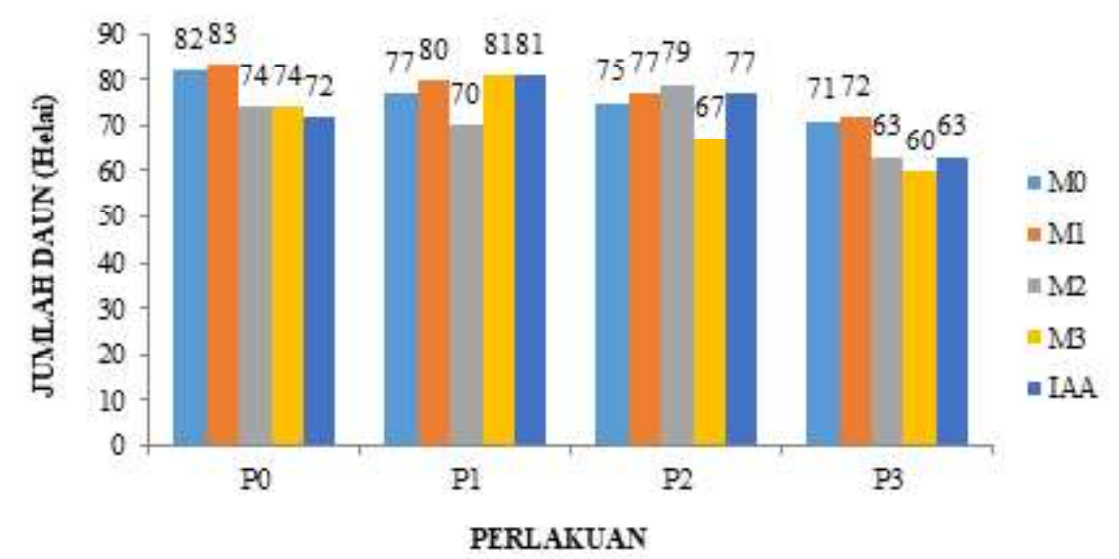

Gambar 2. Rerata jumlah daun tanaman Padi Var. Mpan P-05 setelah 12 MST.

dan M3 (pupuk organik keong mas $2 \mathrm{ml} / \mathrm{L}$ ) menghasilkan jumlah daun paling banyak dibandingkan dengan perlakuan lain baik pada umur 4 minggu, 8 minggu dan 12 minggu setelah pindah tanam. Hal ini dimungkinkan karena aplikasi pupuk organik keong mas $2 \mathrm{ml} / \mathrm{L}$ yang diberikan pada tanaman Padi Var. Mpan P-05 mampu mengimbangi pengaruh paklobutrazol, sehingga jumlah anakan dan jumlah daun bertambah. Akibatnya giberelin meningkat pada meristem pucuk sehingga akan merangsang pembentukan tunas daun dan meningkatkan jumlah daun. Namun, hal ini masih perlu penelitian lebih lanjut. Selain itu, pupuk organik keong mas yang diberikan juga mengandung berbagai komponen seperti fosfor dan kalium yang berperan dalam pertumbuhan.

Fosfor berperan dalam proses pertumbuhan dan perkembangan tanaman. Peranan lain unsur $\mathrm{P}$ adalah membantu pembentukan protein dalam transfermetabolik ATP, ADP, fotosintesis dan respirasi, serta termasuk komponen dari fosfolipid, serta penyimpanan dan pemindahan energi (Leiwakabessy et al., 2003). Fosfor diserap oleh tanaman dalam bentuk terikat dengan molekul lain yang ada pada tumbuhan (Campbell et al., 2000).
Hardjowigeno (2003) mengemukakan kalium berperan penting pada proses fisiologi tanaman. Kalium meningkatkan proses fotosintesis pada tanaman dengan cara meningkatkan fotofosforilasi sehingga menghasilkan ATP dan NADPH yang akan digunakan dalam proses fotosintesis dan metabolisme tanaman (Novizan, 2002). Saat fotosintesis meningkat maka peningkatan leaf area indek (LAI) juga akan meningkat (Marschener, 2003).

\section{Umur tanaman padi Var. Mapan P-05 saat keluar daun bendera}

Pengamatan umur tanaman padi Var. Mapan P05 saat keluar daun bendera dengan berbagai perlakuan paklobutrazol dan pupuk organik keong mas, hasil uji BNT pada tarag 5\% menunjukkan berbeda yang nyata antara perlakuan paklobitrazol dan POC keong mas (tabel3). Rerata umur tanaman padi hitam saat keluar daun bendera tanaman Padi Var. Mpan P-05 dengan berbagai perlakuan konsentrasi paklobutrazol dan pupuk organik keong mas disajikan pada gambar 3.

Berdasarkan gambar 3, terlihat kombinasi paklobutrazol dan pupuk organik keong mas 
Tabel 3. Rerata Umur tanaman padi Var. Mapan P-05 saat keluar daun bendera dengan berbagai perlakuan konsentrasi paklobutrazol dan pupuk organik cangkang keong mas.

\begin{tabular}{|c|c|c|c|c|c|c|}
\hline \multirow{2}{*}{\multicolumn{2}{|c|}{$\begin{array}{c}\text { Konsentrasi Paklobrutazol } \\
\text { (ppm) }\end{array}$}} & \multicolumn{4}{|c|}{ Konsentrasi Pupuk Organik Cangkang Keong Mas (ml/L) } & \multirow{2}{*}{ IAA } \\
\hline & & $\begin{array}{c}\text { M0 } \\
(\mathbf{O m l})\end{array}$ & $\begin{array}{c}\text { M1 } \\
(1 \mathrm{ml}) \\
\end{array}$ & $\begin{array}{c}\mathrm{M} 2 \\
1,5 \mathrm{ml}) \\
\end{array}$ & $\begin{array}{c}\mathrm{M3} \\
(2 \mathrm{ml}) \\
\end{array}$ & \\
\hline \multirow{4}{*}{$\begin{array}{l}\text { Umur Tanaman saat } \\
\text { keluar daun bendera }\end{array}$} & P0 (0ppm) & $68^{\mathrm{d}}$ & $65^{\mathrm{bc}}$ & 53 & $67^{\mathrm{d}}$ & $62^{c}$ \\
\hline & $\mathrm{P} 1$ (5ppm) & $69^{\mathrm{d}}$ & $60^{\mathrm{c}}$ & $60^{\mathrm{b}}$ & $53^{\mathrm{b}}$ & $58^{\mathrm{c}}$ \\
\hline & P2 (10ppm) & $60^{\mathrm{b}}$ & $60^{\mathrm{c}}$ & $53^{\mathrm{b}}$ & $53^{\mathrm{b}}$ & $61^{\mathrm{b}}$ \\
\hline & P3 (15ppm) & $53^{\mathrm{b}}$ & $54^{\mathrm{b}}$ & $53^{\mathrm{b}}$ & $49^{\mathrm{a}}$ & $59^{\mathrm{c}}$ \\
\hline
\end{tabular}

Keterangan: Angka rerata yang diikuti huruf yang sama pada kolom yang sama menunjukkan tidak berbeda nyata pada taraf uji BNT $5 \%$.

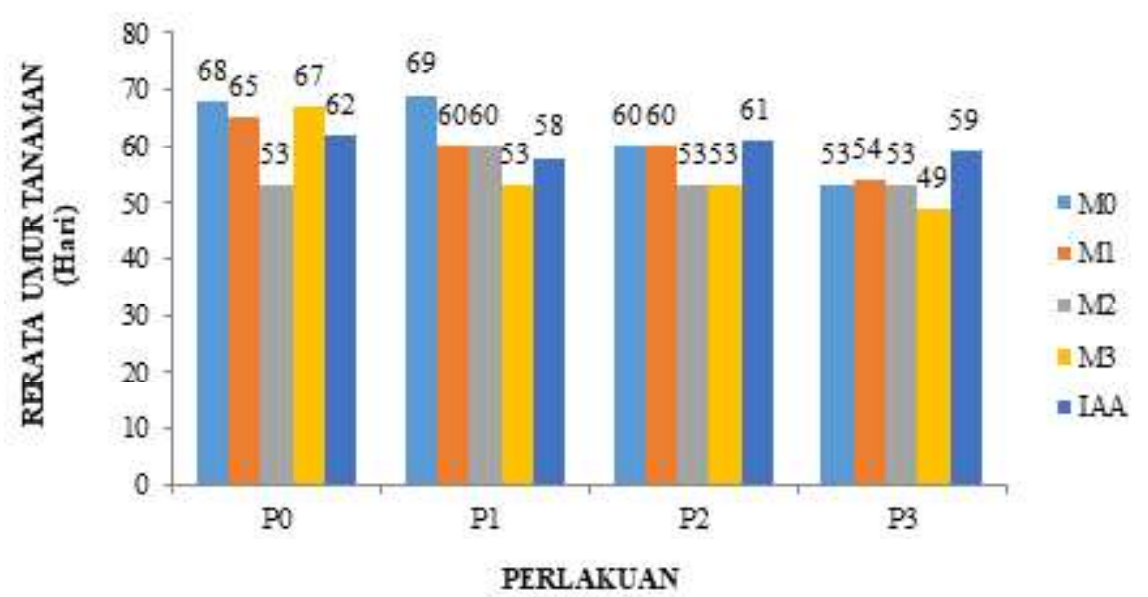

Gambar 3. Rerata Umur tanaman Padi Var. Mpan P-05 saat keluar daun bendera

berpengaruh nyata terhadap hari keluarnya daun bendera. Pada perlakuan P3 (paklobutrazol 15 ppm) dan M3 (pupuk organik keong mas $2 \mathrm{ml} / \mathrm{L}$ ) menunjukkan rerata paling awal munculnya daun bendera dibandingkan dengan pelakuan lain yaitu pada 49 HST. Hasil penelitian ini memiliki kesamaan dengan penelitian Hasal et al. (2012) yang mengungkapkan bahwa aplikasi paklobutrazol 50 ppm serta pupuk organik 2000 ppm dapat memberikan respon yang cepat pada keluarnya bakal bunga pada tanaman anggrek. Hal ini disebabkan bahwa paklobutrazol merupakan inhibitor pada proses biosintesis giberelin, sehingga dapat menghambat pertumbuhan dan mempercepat proses pembungaan secara signifikan (Mangsuroglu etal., 2009; Karaguzel danOrtacesme, 2002).

Pada keong mas mengandung unsur $\mathrm{P}$ dan $\mathrm{K}$ dimana menurut Master, 2009 fosfor dapat mempercepat dan memperkuat benih tanaman muda, mempercepat proses pertumbuhan tanaman menjadi dewasa serta dapat menaikkan presentase bunga menjadi biji atau buah. Unsur K berperan menstransfer fotosintat ke sink sehingga proses tanaman menghasilkan bunga dan buah lebih cepat (Suyamto dan Sumarno, 2010). 


\section{KESIMPULAN}

Kesimpulan yang didapat dari penelitian ini adalah kombinasi paklobutrazol dan pupuk organik keong mas menunjukkan berpengaruh terhadap rerata tinggi tanaman, jumlah daun dan munculnya daun bendera pada tanaman Padi Var. Mpan P-05.

\section{DAFTAR PUSTAKA}

Badan Pusat Statistika (BPS). 2020. Luas Panen dan Produksi Padi Pada Tahun 2019 Mengalami Penurunan Dibandingkan tahun 2018 Masingmasing sebesar 6,15 dan 7,76 Persen. https:// www.bps.go.id/pressrelease/2020/02/04/ 1752/luas-panen-dan-produksi-padi-padatahun-2019-mengalami-penurunandibandingkan-tahun-2018-masing-masingsebesar-6-15-dan-7-76-persen.html. Diakses 10 Februari 2020.

Campbell, N.A., J.B. Reece., and L.G. Mitchell. 2000. Biologi. Penerbit Erlangga, Jakarta.

Chaney, E. R. 2005. Paclobutrazol: More Than Just a Growth Retardant. Pro-HortConference, Peoria, Illinois, February 4th. Department of Forestry and Natural Resources. Purdue University.

Chaniago. 2015. Teknik Pembuatan Zat Pengatur Tumbuh (POC) dari Beberapa Mollusca dan Aplikasinya Terhadap Pertumbuhan dan
Produksi Tanaman Selada (Lactuca sativa) dengan Hidroponik FHS (Floating Hydroponicc System). Skripsi. Universitas Islam Sumatra Utara.

Hasal, R., Sarawa, dan Sandimantara, R. 2012. Respon tanaman anggrek Dendrobium sp. terhadap pemberian paklobutrazol dan pupuk organik cair. J. Argonomi. 1(1):71-78.

Karaguzel, O. and V. Ortacesme. 2002. Influence of paclobutrazol on the growth and flowering of Bougainvillea glabra 'Sanderiana'. Ziraat Fakultesi Dergisi, Akdeniz Universitesi, 15(1): 79-84.

Leiwakabessy FM, Wahjudin UM, Suwamo. 2003. Kesuburan Tanah. Jurusan Tanah. IPB, Bogor.

Mansuroglu, S., O. Karaguzel, V. Ortacesme and M.S. Sayan. 2009. Effect of paclobutrazol on flowering and colour of Consolida orientalis.Pak. J. Bot., 41(5): 2323-2332.

Marschener, H. 2003. Mineral Nutrition of Higher Plant (ed 2). California: San Diego. 188p.

Master. 2009. Unsur Hara Fosfor. http://pupukdsp.com/ indeks.php/pupuk-tanaman/Unsur-HaraFosfos_P. Html (diakses 5 mei 2015)

Novizan. 2002. Petunjuk Pemupukan yang Efektif. Agromedia Pustaka, Jakarta. 